\title{
ON THE OCGURRENCE OF SEX-LINKED VARIATIONS IN TWINS
}

\author{
BY \\ C. E. KELLETT, M.D., M.R.C.P. \\ (From the Babies' Hospital, Newcastle-on-Tyne.)
}

During the past few years it has become apparent that disease is by no means the necessary response of an organism to infection, and further, that the type of disease produced depends not only on the nature of the infecting agent but also on the state of the organism infected. So has room been found for considerable speculation, much of which could be confirmed, or disposed of, were it adequately controlled.

Such a control of the soil factor, as opposed to that of the seed, would apparently be adequately provided for, if the disease processes were studied in a number of identical twins, as suggested by Galton ${ }^{1}$. Despite his advocacy and the papers published in 1911 by Cockayne ${ }^{2}$ and in 1925 by Murray $^{3}$, this method of approach, laborious yet of considerable promise, has been comparatively neglected in this country. In Germany particularly, during the past few years, has an attempt been made to acquire insight by this means. Not only has a mass of somewhat heterogeneous information been collected on the response of twins to the more common infectious diseases and analyzed in papers such as those of Glatzel $^{4}$, but the problem has been rather more widely reviewed by Stransky ${ }^{5}$, Curtius ${ }^{6}$, Siemens ${ }^{7}$, and von Verschuer $^{8}$, as well as by Francioni ${ }^{9}$ in Italy, and Apert ${ }^{10}$, and more recently Pommert ${ }^{11}$, in France.

This method of approach has been applied by Siemens ${ }^{12}$ to the study of skin conditions, by Korkhaus ${ }^{13}$, Siemens and Hunold ${ }^{14}$ to those of the mouth and teeth, and has in particular yielded information on the constitutional factors involved in the development of tuberculous infection, of insanity and crime, through the work more especially of Diehl and von Verschuer $^{15}$ and of Lange ${ }^{16}$. As a deliberate control identical twins were employed in a feeding experiment by Bernheim Karrer ${ }^{17}$.

TABLE 1.

SEX INCIDENCE OF TWINS.

\begin{tabular}{l|c|cc}
\hline & Male pairs. & Female pairs. & Mixed pairs. \\
\hline $\begin{array}{c}\text { German Empire } \\
\quad(1906-1911)\end{array}$ & 49,425 & 46,637 & 58,382 \\
$\begin{array}{c}\text { United States } \\
\quad(1921)\end{array}$ & 6,639 & 6,484 & 6,898 \\
$\begin{array}{c}\text { Nichols data } \\
\left(\text { Newman }{ }^{18}\right)\end{array}$ & 234,497 & 264,098 & 219,312 \\
\hline
\end{tabular}


The justification for all such work, admittedly tedious and painstaking, resides in the belief that so-called identical twins are monozygotic and have arisen from a single ovum fertilized by a single spermatozoon. Such twins must of necessity ke of the same sex, and since the laws of chance demand that there should be as many like-sexed dizygotic twins as there are of unlike sex, the discrepancy between the actual incidence as shown in Table 1 and the theoretical ratio of $1: 2: 1$ constitutes a statistical proof in favour of the cxistence of such twins. The only satisfactory explanation of this discrepancy is, as Newman ${ }^{18}$ points out, the assumption that nearly half the like sexed twins are monozygotic, ' and hence morphologically stand for but one individual to a pair.' From these figures Weinberg ${ }^{19}$, and many after him, have arrived at an estimate for the relative incidence of such identical twins, which Bonnevie and Sverdrup ${ }^{20}$ have shown to be in reasonable agreement with those arrived at from a clinical study of the fœetal membranes. About 21 per cent. then, only, of all twins born are probably identical twins. It should, however, be noted that direct evidence of monozygotic twinning in man was not forthcoming until 1922, when Arey²1 described a specimen of twin embryos in which he could actually demonstrate their origin from a ' single yolk sac and hence from a single ovum.'

The incidence of multiple births has recently been studied by Greulich"2 in a series of 21 different countries. The percentage of multiple births was found to vary remarkably for different countries, ranging from 1.59 twin births in Denmark to $0 \cdot 40$ in Colombia. On the average, as is generally received, he found that there is one set of twins for each 85 confinements, while the ratio of other multiple births-triplets 1 to $85.3^{2}$, quadruplets 1 to $87 \cdot 3^{3}$ - is in close agreement with those demanded by Zeleny's:3 hypothesis.

The variation which may occur within a community, from which emerges the hereditary nature of twinning, has perhaps most clearly been shown by Bonnevie and Sverdrup" who have taken advantage of the relative geographical isolation of such communities as those in the valley of the River Orkla, in Norway. While the average percentage of twin-births in the Norwegian population proved to be $1 \cdot 46$, their twin families gave 3.25 and in special twin-lines the percentage was raised even to $8 \cdot 23$.

Neither they. nor Davenport"-1, nor indeed any one else, has shown how this tendency is transmitted. This in part would seem to be due to the possibility that a different hereditary mechanism may be at play in the case of dizygotic as opposed to monozygotic twins. That this is the case is strongly suggested by the different relations that exist between the age of the mother and the percentage of monozygotic and dizygotic births. As first shown by Weinberg ${ }^{19}$, there is an increase in the frequency of dizygotic twin births until the age of forty, but little or no change in the frequency of monozygotic twin births.

Not only are twins relatively rare, but like-sexed twins require careful examination before it can be determined whether or not they are identical twins. Since such a determination must depend in the main upon the 
establishment of certain deep-seated resemblances; in this case our very reason for studying monozygotic twins, the necessity for certain rigid and accepted standards is apparent.

The elaboration of such standards is by no means easy, for even when such information is available, the existence of multiple or single chorions cannot be said to constitute unimpeachable evidence. Curtius ${ }^{25}$, in a recent study of twins whose birth history had apparently been accurately recorded, found 7 pairs out of a total of 19 like-sexed pairs that were identical. Of these seven, three pairs were mono-chorial, 3 di-chorial, and 1 , because of the poor condition of the fœetal memtrances, had been recorded as being doubtful. Again, von Verschuer $^{26}$ has recently described an example of mono-chorionic though apparently dizygotic twins. It is as a result of such findings, that, as Newman'i suggests, 'such careful and capable students of human twins as Siemens, v. Verschuer, and Dahlberg have been forced to rely exclusively upon the similarity method of diagnosis and to give only very secondary consideration to fotal membranes '; and, indeed, such an attitude implies no more than a recognition of the possibility that the twinning division may take place prior to the trophoblast stage, a possibility that may apply not only to twinning but also to other multiple births, for Komai and Fukuoko ${ }^{28}$ describe what they believe to be a set of dichorionic identical triplets.

The similarity method of diagnosis has been elatorated in the main by Wilder $^{29}$, Thorndike ${ }^{30}$, Danforth ${ }^{31}$, Bonnevie ${ }^{32}$, Cummins ${ }^{33}$, Newman ${ }^{34}$, Dahlberg $^{35}$, Stocks ${ }^{36}$, and Lauterbach ${ }^{37}$. A considerable amount of data dealing with hand and foot prints, measurements, left-handedness, mirror reversal, and so on has been collected; and Fisher ${ }^{38}$, moreover, has submitted Thorndike's and Lauterbach's results to statistical examination. Nevertheless, though it is conceivable that, as Newman maintains, by this means even the most refractory case may be resolved, there is not only an obvious danger in such a method of approach-Hogben ${ }^{39}$, for instance, quotes Stocks $^{36}$ as having "rightly remarked that " in no branch of scientific investigation is the circular method of reasoning so common", - but also a very marked subjective element is, as Stocks has demonstrated, still present, so that as he says ' it is therefore surprising to find with what assurance many writers on the question of twins regard their own ability to diagnose the monozygotic from the dizygotic with certainty, which can only be explained ty the fact that no satisfactory check has so far been devised as to whether the diagnosis was right or wrong.'

My purpose in this paper is to call attention to a certain small group of like-sexed twins in which for other and more fundamental reasons their nature is known, and which therefore would appear to constitute just such a check.

In man, as well as in many animals, a number of genes appear to be located in the sex chromosome, and are linked with sex in a curious and clear cut way. The female somatic cells have each two chromosomes (XX), one from each parental germ cell, while the male has only one $\mathbf{X}$ chromosome 
and this is derived from the egg. It is associated with the so-called Y-chromosome which carries few active genes. Now in the female an affected chromosome $\mathbf{X}$ will as a rule be balanced by the second $\mathbf{X}$-chromosome, but in the male such a balance will not be achieved, and may become manifest as a sex-linked malady, such as those recently reviewed by Davenport ${ }^{40}$. - Thus the chromosomes offer a complete explanation of a very complicated form of hereditary behaviour' (Gates $\left.{ }^{11}\right)$.

It would seem impossible for only one of like-sexed monozygotic twins to be affected with such a hereditary condition; that, however alike such twins may be, as were for instance those described by Nettleship ${ }^{42}$, they must be dizygotic.

Examples of sex-linked conditions occurring in twins are of a necessity somewhat rare, and with the exception of the tantalizingly incomplete descriptions given ty Nettleship of two lots of apparently identical twins in which only one of each was affected with colour blindness, in pedigrees where they have occurred little information has been given concerning them. Fischer ${ }^{43}$, Gould ${ }^{44}$, and v. Manteuffel ${ }^{45}$ have recorded pedigrees of hæmophilia in which both twins were affected, and Sadler $^{46}$ and de Lacy ${ }^{47}$ in which only one of the like-sex twins was affected. $\mathbf{A s h}^{48}$ has recorded briefly a pedigree of sex-linked microphthalmia in which only one of like-sexed twins was affected, and further instances of colour blindness in twins have recently been summarized by Waardenburg ${ }^{49}$.

The following case of clearly defined sex-linked hereditary nystagmus occurred in only one of like-sexed twins, who are therefore, it is suggested, of dizygotic origin. It is reported in detail in the belief that an accumulation of such records will ultimately serve to discredit or else confirm the present methods of distinguishing between the two types of twins.

On the present assumption that monozygotic twins resemble one another more closely than do dizygotic twins, the value of known dizygotic twins as checks varies directly as the degree in which they resemble one another.

It is interesting therefore to note at this point, the paradoxical dissimilarity that has been noticed by Reichle ${ }^{50}$ and others to occur in conjoined twins; for these as Newman"1 maintains, constitute in all probability the only group of twins ' that are indubitakly monozygotic.' This dissimilarity is probably adequately explained by him on the assumption that it is no more than the inevitable expression of the twinning division having occurred relatively late in their development, when the two halves of the embryo will no longer be equipotent but one half will have right-handed tendencies and the other left-handed. It follows from this that the earlier twinning division takes place the more alike identical or monozygotic twins will tend to be, and this may explain why in certain series the most obviously monozygotic twins have been di-chorionic.

On January 20th, 1933, A. B., aged $2 \frac{1}{4}$ years, was brought to the Babies' Hospital by his mother because of his failure to put on weight, and his recurrent attacks of fever and cough. During the past 4 months, the child had had 3 such attacks. The first one lasted for about a fortnight and was associated with a fever, his 
temperature on the occasion it was taken being $102^{\circ}$. During this period he lost about $2 \mathrm{lb}$. in weight; at that same time his brother, though he appeared to be quite well, also lost about $1 \mathrm{lb}$. in weight. Since then neither of the twins had gained weight regularly, and A. B. had had two further attacks of fever, though in each case they were of rather shorter duration.

The health of the twin brother T. B., and of the only other child, a boy aged 5, had not in any way given the mother anxiety, and she was not concerned at the very marked and coarse lateral nystagmus that $A$. B. alone showed, since it was well known in her family that for generations certain of the male children had been so affected.

Her husband was one of twins, and twins had been known to occur in his family, but were reputed never to have occurred in hers. Both she and her husband were healthy, an aunt, however, whom the twins had frequently visited had died that Christmas of Addison's disease.

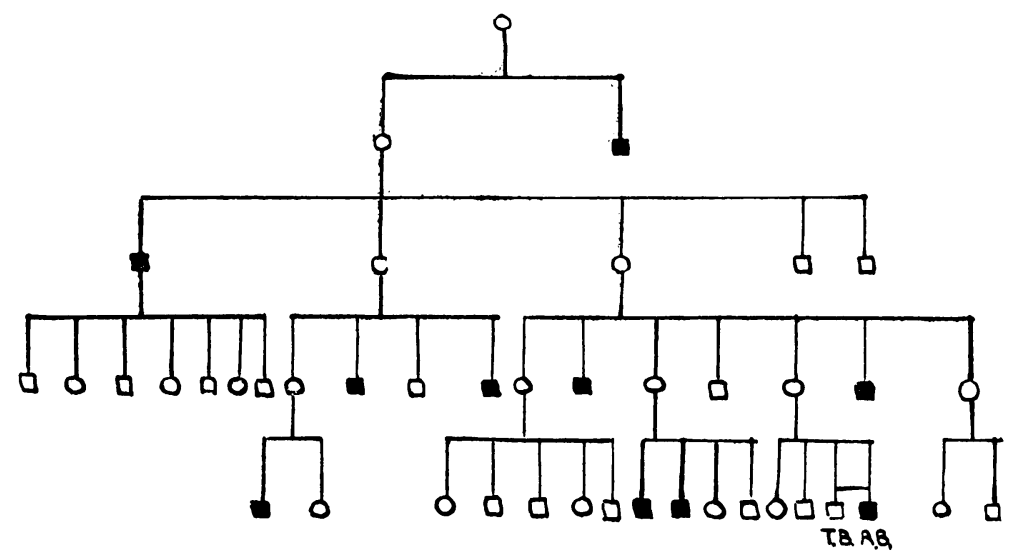

GRAPH I.-Pedigree of twins.

Graph I summarizes the pedigree of the twins. Their great great grandmother was born in Northern Ireland, and it is a tradition of the family that the nystagmus had been present in certain of the men of the family for many former generations. This nystagmus appears to have been invariably definite and clear cut, and to have been sex-linked.

Such pedigrees of sex-linked hereditary nystagmus are relatively rare, but examples have been published by Owen ${ }^{51}$, Clarke ${ }^{52}$, Caspar ${ }^{53}$, Muller ${ }^{54}$, Evans $^{55}$, Auden ${ }^{56}$, Nettleship ${ }^{57}$, Nodop ${ }^{58}$, Cockayne ${ }^{59}$, Englehaard ${ }^{60}$, Waardenburg ${ }^{61}$, Hemmes ${ }^{62}$, and Holm ${ }^{63}$. The ætiology of this condition is obscure. Nettleship considered it to be often an expression of partial albinism, but as Cockayne points out such an explanation cannot apply to the family whose pedigree he gives, who are Italians, and darkly pigmented. Both A. B. and T. B. too have dark brown eyes, and showed on examination no gross deficiency in retinal pigmentation. In short, little is known of this condition, which is of interest here since it so sharply distinguishes one twin from the other.

It is therefore unfortunate that superficially the twins apart from their pigmentation do not very closely resemble one another. As their photographs show there are distinct differences in the shapes of their heads. Their response, however, to certain external factors appears to have been similar. 
Though A. B. when first weighed was $\frac{1}{2}$ lb. lighter than T. B. the variations that took place in their weight charts even during the last year, when A. B. was noticed to be ill, are, as shown in Graph II, very similar.

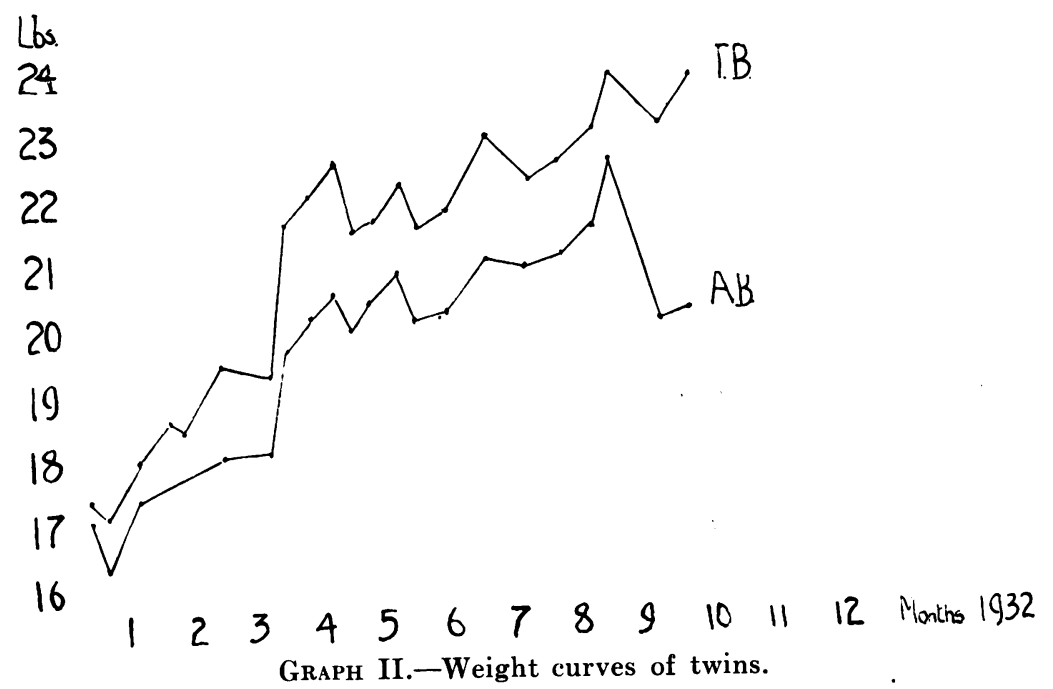

Both showed on being tested with tuberculin intra-dermally a markedly positive response, and presented on $\mathrm{X}$-ray examination a very similar picture of increase in the peri-hilum shadows; and the discrepancy between their mode of response to this infection, for in the case of $\mathbf{A}$. B. this relatively recent tuberculous infection was considered to be responsible for the bouts of unexplained fever, was to some extent dispelled by T. B. subsequently developing in the early part of February an apparently identical febrile attack.

Siemens ${ }^{64}$ has stated that the probability of two twins with identical hair and eye colouring being dizygotic is remote; yet in these two boys the colouring of the hair, a rather peculiar ashen blond with a tawny glint, and of the eyes, which were a darkish brown like those of the father, and unlike the blue eyes of the mother and eldest boy, were identical. He insists, however, that in ' isolated cases' this would not suffice for diagnosis, and gives a list of other traits in which monozygotic twins usually show strong resemblances to one another and dizygotic twins only rarely; a scheme which he points out can ke extended as desired, through the inclusion of other traits and is therefore 'capable of unlimited development.' Such a scheme, which has also been adopted by Newman, and is generally approved, would appear to be one singularly susceptible of circular reasoning, and its appraised quality of unlimited extension quite peculiarly suspect. For it is clear that if twins are to be employed for the purpose of distinguishing between the operation of external and inborn factors, the briefer the scheme adopted in determining their identity, and the more it is dependent on simple anatomical factors, capable if possible of arithmetical expression, the better. Schemes of this general type, some of which have been recently reviewed by 
Komai $^{65}$, while often comprehensive, are so vague and ill-defined that they scarcely admit of being checked by cases of the type that is being descriked, and indeed would not seem to offer the clinician much assistance in the classification and recording of the few isolated but significant cases of disease in twins which he is likely to encounter.

Stocks has endeavoured to fill this want. Facial resemblance and pigmentation are alike rejected by him as being variable and simply of ancillary value, and he believes that finger-print resemblances between corresponding fingers in twins furnishes the best means of separating monozygotic from dizygotic twins. 'This depends on the criterion that monozygotic twins have six or more patterns alike on corresponding fingers of the same-sided hands, whilst dizygotic have six or less alike; in the ambiguous case when six are alike the diagnosis is completed by comparing the differences in height and four simple head measurements with tabulated values.' His definition of alikeness is confessedly rather vague, and is that to a ' casual examination they should appear the same,' though this ' casual examination' implies an examination that only just falls short of counting the ridges, and a very close resemblance.

Both the finger patterns and the palm patterns, that are inserted because of their documentary value, show differences that, in the case of the finger patterns at any rate, so far as his scheme is concerned, are significant.

Had it keen necessary to go further it is clear from Stocks' table of limiting differences that the measurements of the twins are such as to reaffirm their dizygotic origin.

TABLE 3.

Limiting Differences for diagnosis of LIKe-SEXed TWINS (Stocks).

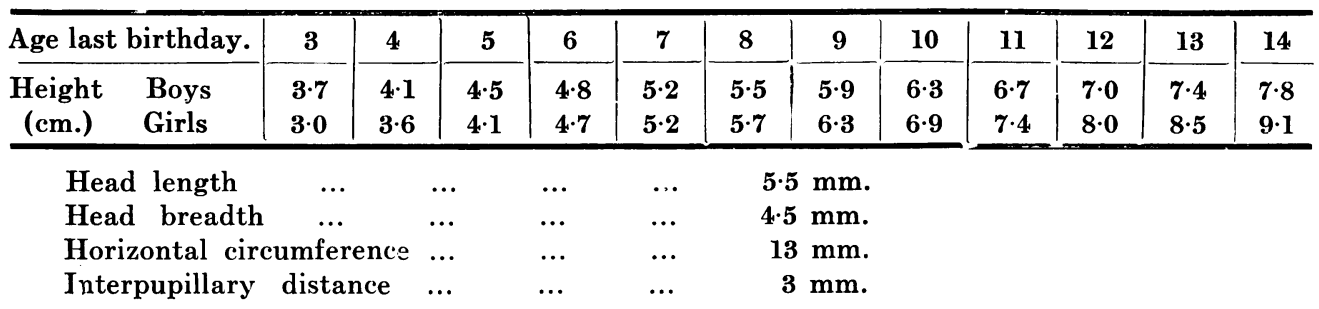

TABLE 4.

Measurement of twins.

\begin{tabular}{|c|c|c|c|c|c|}
\hline & & & & A. B. & T. B. \\
\hline Height, standing & $\cdots$ & $\cdots$ & $\ldots$ & $\mathbf{3 0}^{\prime \prime}$ & $30 \frac{1}{4} "$ \\
\hline Height, sitting & ... & ... & ... & $17 \frac{1}{2} "$ & $18^{\prime \prime}$ \\
\hline Weight & $\ldots$ & $\ldots$ & $\ldots$ & $20 \mathrm{lb} .11 \mathrm{oz}$. & 23 lb. $4 \frac{1}{2}$ oz. \\
\hline Skull, length ... & $\ldots$ & $\ldots$ & ... & $154 \mathrm{~mm}$. & $165 \mathrm{~mm}$. \\
\hline Skull, breadth & $\cdots$ & $\ldots$ & $\cdots$ & $130 \mathrm{~mm}$. & $145 \mathrm{~mm}$. \\
\hline Cephalic index & $\ldots$ & $\ldots$ & $\ldots$ & 84 & 88 \\
\hline Horizontal circ. & $\cdots$ & $\ldots$ & $\ldots$ & $18_{4}^{1 \prime \prime}$ & $19 \frac{3}{4} "$ \\
\hline Supra-auricular trans & verse & irc. & $\ldots$ & $12^{\prime \prime}$ & $14^{\prime \prime}$ \\
\hline Colour of eyes ... & $\ldots$ & $\ldots$ & $\ldots$ & Dark brown & Dark brown \\
\hline Colour of hair & $\ldots$ & ... & ... & Very fair & Very fair \\
\hline Whorl of head hair & $\cdots$ & ... & ... & Clock-wise & Clock-wise \\
\hline Handedness $\quad \ldots$ & $\ldots$ & $\ldots$ & $\ldots$ & Right & Right \\
\hline
\end{tabular}



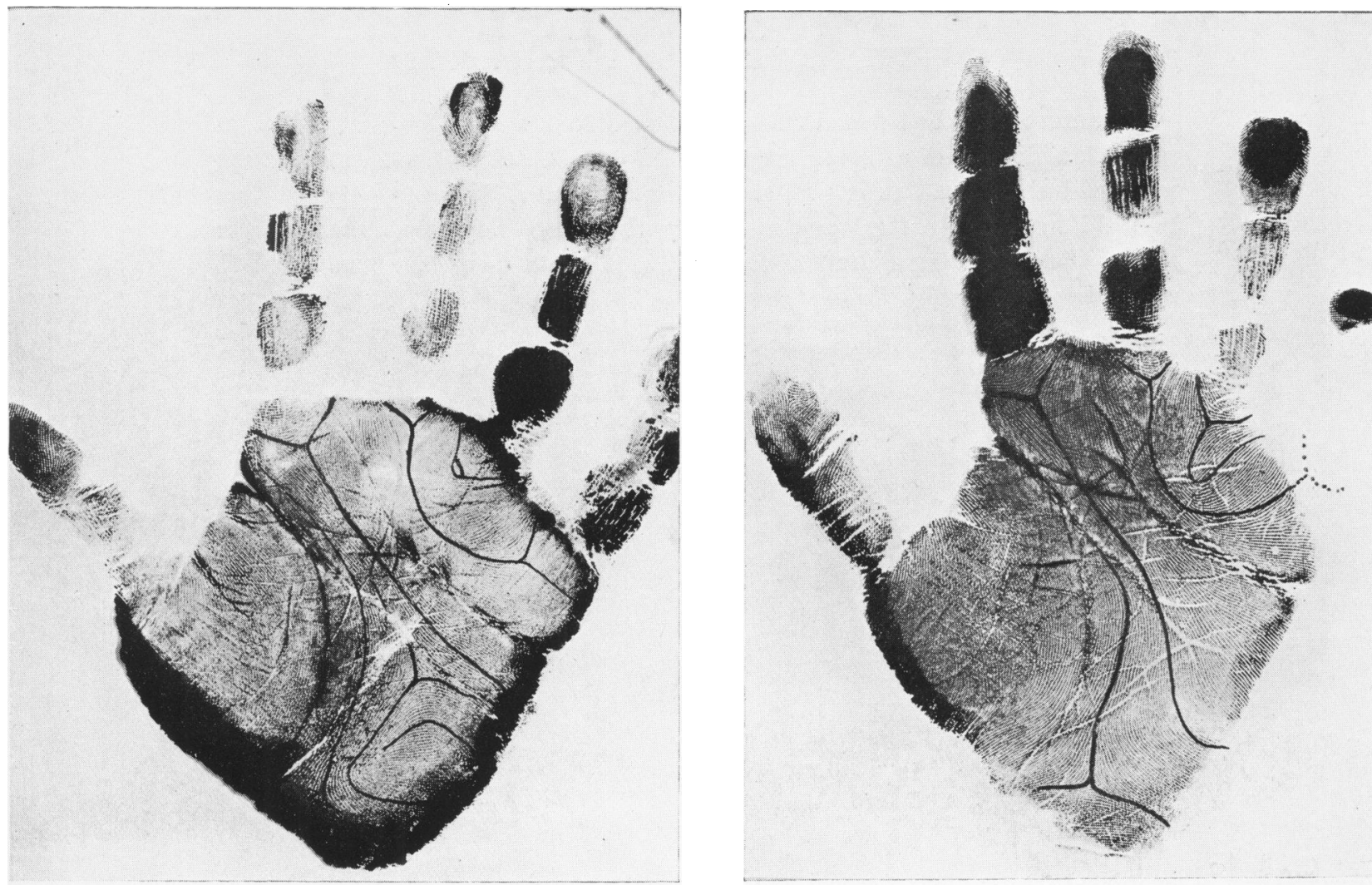

A. B., right hand.

T. B., right hand.
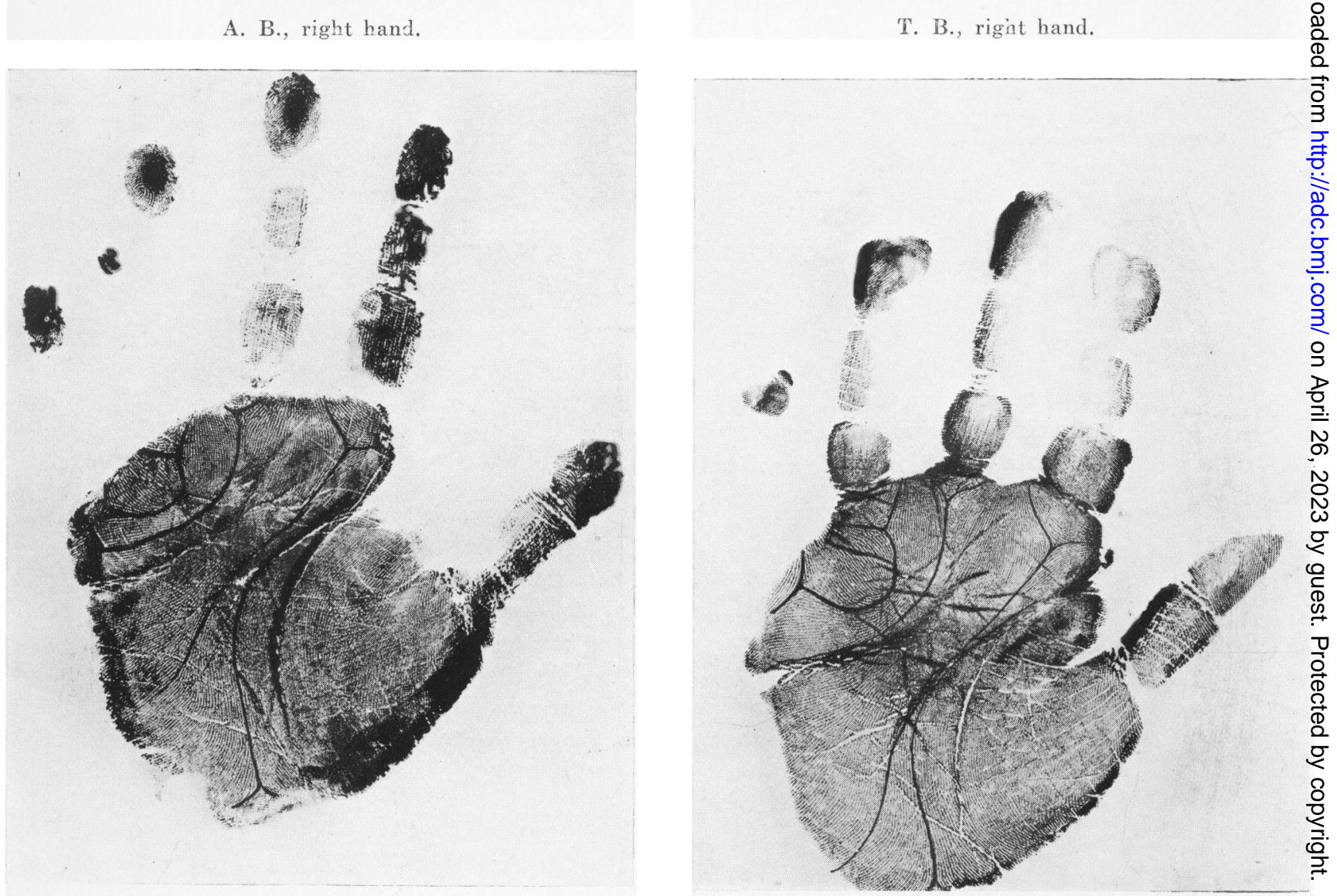

A. B., left hand.

T. B., left hand. 
Lauterbach $^{37}$ has described two pairs of twins so alike that he would have classified them as being monozygotic were it not that in each case they were of unlike sex. It is probable then that the differences between these two children are greater than in theory they need have been, and to that extent their value as a check is impaired. As it is they have confirmed the method laid down by Stocks.

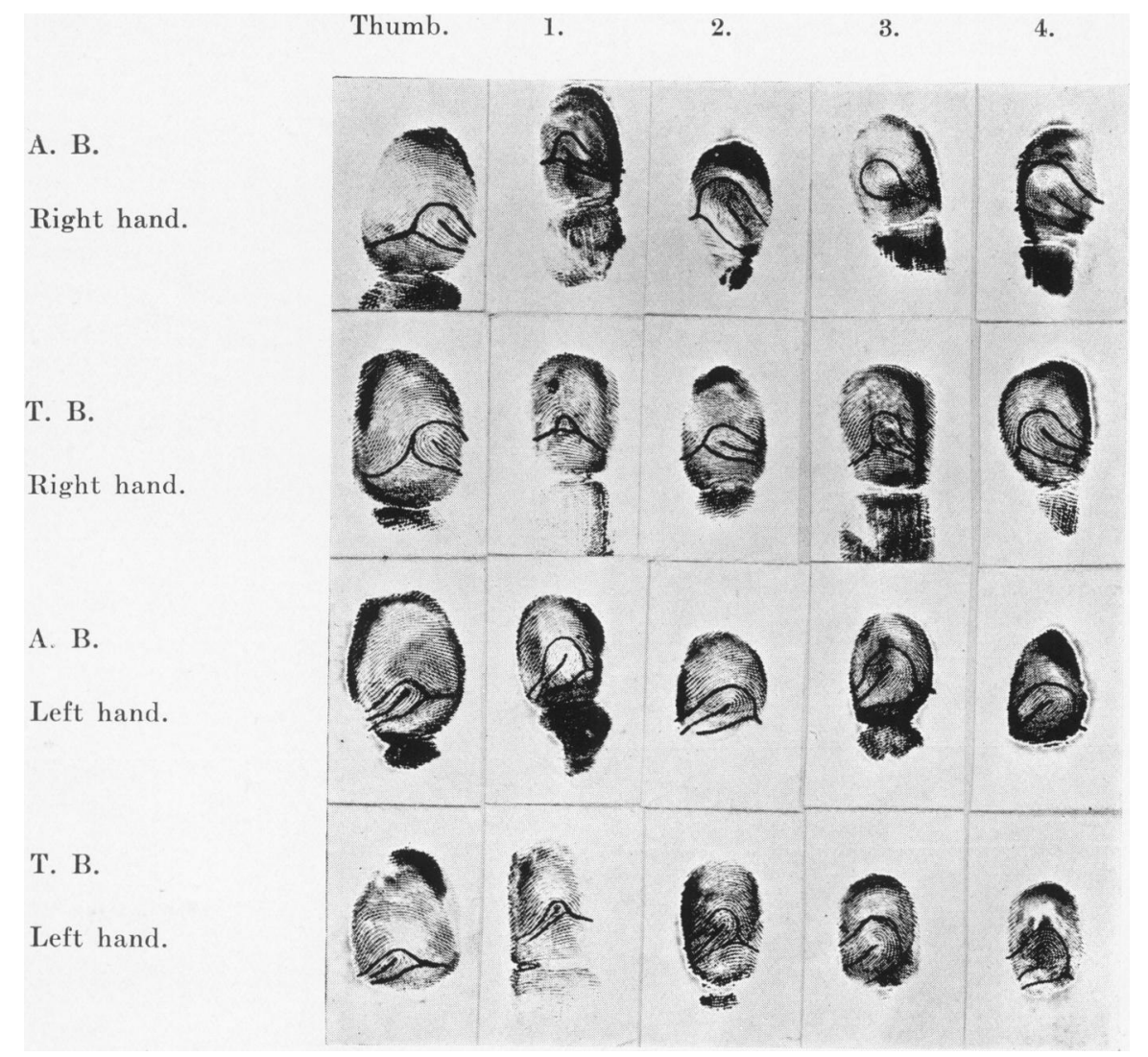

Until, however, such methods for classifying them are adequately checked, the degree of identity of twins, if they are to be employed in medicine as controls, should be determined by methods that admit of accurate definition and recording.

\section{Summary.}

A body of thought has during the past few years arisen that tends to emphasize once more the rôle played by the constitution of the infected organism in determining the type of disease pattern.

Just as it was found essential to subject the rôle played by the infective agent to control, so too an attempt should be made to control this second factor. Such a control would seem to be almost ideally provided were such 
disease processes studied in a number of pairs of known monozygotic and dizygotic twins.

There is sound statistical evidence that these two types of twins do exist, but the methods commonly employed in distinguishing between these two types of twins are based upon a statistical consideration of their resemblances, and offer, unless adequately checked, an example of argument in a circle; a fault in logic peculiarly unfortunate seeing the manner of its employment.

The method proposed by Stocks is sufficiently definite for it to admit of a check being applied, and it is suggested that where only one of like-sexed twins are affected by a sex-linked character, such twins are dizygotic and constitute such a check.

Such a pair of twins is reported in detail; though they were not sufficiently alike to test Stocks' scheme severely, they had many features such as pigmentation, variation in growth and response to infection in which they closely resembled one another.

It is a pleasure to thank Dr. Elsie B. Wright for her kindness in calling my attention to this case of nystagmus which was admitted to the Babies' Hospital under her charge.

\section{REFERENCES.}

1. Galton, F., J. Anthrop. Inst., London, 1876, V, 324 \& 391.

2. Cockayne, E. A., Brit. J. Child. Dis., London, 1911, VIII, 487.

3. Murray, G. R., Lancet, London, 1925, i, 529.

4. Glatzel, H., Ztscher, f. klin. Med., Berlin, 1931, CXVI, 632.

5. Stransky, E., Monatschr. f. Kinderh., Berlin, 1930, XLVIII, 406.

6. Curtius, F., \& Korkhaus, G., Ztschr. f. Konstitut., Berlin, 1930, XV, 229.

7. Siemens, H. W., Die Zrvillingspathologie, Berlin, 1924.

8. v. Verschuer, O., Ergebn. d. Inn. Med. u. Kinderh., Berlin, 192\%, XXXI, 35.

9. Francioni, C., Riv. di. clin. pediat., Firenze, 1919, XVII, 57.

10. Apert, E., Les Jumeaux, Etude biologique, physiologique et medicale, Paris, 1923.

11. Pommert, X., Thése de Paris, 1930.

12. Siemens, H. W.. Arch. f. Dermat. u. Syph., Berlin, 1924, CXIVII, 210.

13. Korkhaus, G., Viertelj. schr. $f$. Zahnheilk, Berlin, 1929, XLV, 414.

14. Siemens, H. W., \& Hunold, Arch. f. Dermat. u. Syph., Berlin, 1924, CXLVII, 409.

15. Diehl, K., \& v. Verschuer, O., Beitr. z. Klin. d. Tuberk., Berlin, 1930, LXXV, 206.

16. Lange, J., Allg. Ztschr. f. Psychiat., Berlin, 1929, XCIX, 122.

16. Lange, J., Verbrechen als Schicksal, Leipzig, 1929.

17. Bernheim-Karrer, J., Ztschr. f. Kinderh., Berlin, 1929, XLVII, 427.

18. Newman, H. H., Biology of Twins, Chicago, 1917.

19. Weinberg, W., Ztschr. f. Geburtsh. u. Gynak., Stuttgart, 1902, XLVIII, 94.

20. Bonnevie, K., \& Sverdrup, A., J. Genetics, London, 1926, XVI, 125.

21. Arey, L. B., Anat. Rec., Philad., 1922, XXIII, 245.

22. Greulich, W. W., Am. Naturalist, N.Y., 1930, LXIV, 142.

23. Zeleny, C., Science, N.Y., 1921, LIII, 262.

24. Davenport, C. B., Am. Naturalist, N.Y., 1920, LIV, 122.

25. Curtius, F., Arch. f. Gynäk., Berlin, 1930, CXL, 361.

26. v. Verschuer, O., Munchen Med. Wchnschr., Munich, 1925, LXXII, 184. 
27. Newman, H. H., J. Hered., Washington, 1931, XXII, 41.

28. Komai, T., \& Fukuoko, G., Loc. cit., 233.

29. Wilder, H. H., Am. J. Anat., Philad., 1904, III, 387.

30. Thorndike, E. L., J. Philos. Psychol., Pa., 1905, II, 547.

31. Danforth, C. H., J. Hered., Washington, 1919, X, 399.

32. Bonnevie, K., J. Genetics, London, 1924, XV, 1.

33. Cummins, H., Anat. Rec., Philad., 1931, XLVI, 179.

34. Newman, H. H., J. Hered., Washington, 1931, XXII, 201.

35. Dahlberg, G., Twin Births and Twins from a Hereditary Point of Viez, Stockholm, 1926.

36. Stocks, P., Ann. Eugenics, Cambridge, 1930, IV, 49.

37. Lauterbach, C. E., Genetics, N.Y., 1925, X, 509.

38. Fisher, R. A., Ibid., 1925, X, 569; 1919, IV, 489.

39. Hogben, L., Genetic Principles in Medicine and Social Science, London, 1931.

40. Davenport, C. B., Genetics, N.Y., 1930, XV, 401.

41. Ruggles Gates, R., Heredity in Man, London, 1929, 23.

42. Nettleship, E., Trans. Ophth. Soc., London, 1912, XXXII, 309.

43. Fishcher, M., Zur Kenntnis der Hæmophilie, Munchen, 1889.

44. Gould, A. A., Med. \& Surg. J., Boston, 1857, LVI, 500.

45. v. Manteuffel, 7., Deuts. med. Wochschr., Leipzig, 1893, XIX, 665.

45. Sadler, E. A., Birmingham Med. Rev., Birmingham, 1898, XLIV, 45.

47. de Lacy, M., Lancet, London, 1931, i, 1074.

48. Ash, W. M., Brit. Med. J., London, 1922, i, 558.

49. Waardenburgh, P. J., Bibliographica Genetica, 'S-Gravenhage, 1923, VII, 557.

50. Reichle, H. S., Biol. Bull., 1928, LVI.

51. Lloyd Owen, D. C., Ophth. Rev., London, 1882, I, 239.

52. Clarke, E., Ophthalmoscope, London, 1903, I, 86.

53. Caspar, L., Zbl. f. prakt. Augenh., Leipzig, 1908, XXXII, 199.

54. Muller, E., Dtsch. Z. f. Nervenheilk., Leipzig, 1908, XXV, 467.

55. Evans, Rep. Soc. Study Dis. in Child., 1908, VIII, 399.

56. Auden, G. A., Trans. Ophth. Soc., London, 1911, XXI, 184.

57. Nettleship, E., Loc. cit., 177.

58. Nodop, H., İnaug. Diss., Leipzig, 1912.

59. Cockayne, E. A., Proc. Roy. Soc. Med., London, 1914, Sect. Neur., Ophth., \& Otol., IV.

60. Englehard, C. F., Ztschr. f. d. ges. Neurol. i. Psych., Berlin, 1915, orig., XXVIII, 319.

61. Waardenburg, Loc. cit., 113.

62. Hemmes, G. D., Zeit. f. Aug., Berlin, 1926, LVIII, 413.

63. Holm, E., Acta Ophth.. Stockholm, 1927, IV, 20.

64. Siemens, H. W., J. Hered., Washington, 1927, XVIII, 201.

65. Komai, T., Quarterly Rev., Biol., Baltimore, 1928, III, 408. 